\title{
MEASUREMENTS OF PRESSURE DISTRIBUTIONS ON A ROTOR BLADE USING PSP TECHNIQUES
}

\author{
KI-DONG KIM ${ }^{1}$ AND KI-JUNG KWON ${ }^{2}$ \\ ${ }^{1}$ Aircraft System Engineering Dept., University of Science and Technology (UST), \\ Daejeon, South Korea. \\ ${ }^{2}$ Aerodynamics and Structures Dept., Korea Aerospace Research Institute (KARI), \\ Daejeon, South Korea. \\ kjkwon@kari.re.kr
}

\begin{abstract}
Surface pressure distributions on a rotating blade were measured by using pressure sensitive paint (PSP) to understand aerodynamic characteristics of a rotor blade. The present study was conducted to investigate the PSP techniques for measuring the pressure distributions on a rotor blade. In order to perform the experiment, the PSP was required to response very fast due to rapid pressure fluctuations on a rotor blade. High energy excitation light source was also needed to acquire proper intensity images in a short excitation time. The techniques were based on a lifetime method. Qualitative pressure distributions on an upper surface of small scale rotor in hovering condition were measured as a preliminary experiment prior to forward flight conditions in the KARI low speed wind tunnel laboratory. From measured pressure distributions, striking pressure gradient was observed on an upper surface of rotor blade and the resulting pressure showed expected gradient depending on different collective pitch angles.
\end{abstract}

ABSTRAK: Pengagihan tekanan permukaan ke atas berbilah putar disukat menggunakan cat sensitive tekanan (pressure sensitive paint $(P S P)$ ) untuk memahami sifat-sifat aerodinamik suatu berbilah putar. Kajian telah dijalankan untuk menyelidik teknik-teknik $P S P$ dengan mengukur agihan tekanan ke atas suatu berbilah putar. Agar eksperimen dapat dijalankan dengan baik, PSP harus bertindak cepat kerana tekanan naik turun dengan pantas ke atas berbilah putar. Sumber cahaya ujaan tenaga tinggi diperlukan untuk mendapatkan imej keamatan wajar dalam jangka masa ujaan yang pendek. Teknik-teknik tersebut terhasil daripada kajian semasa hayat. Agihan tekanan kualitatif ke permukaan atas berskala kecil pemutar dalam keadaan mengapung diukur sebagai permulaan eksperimen, sebelum penerbangan kehadapan dalam makmal terowong angin laju rendah KARI. Daripada agihan tekanan yang disukat, kecerunan tekanan yang ketara diperolehi daripada permerhatian terhadap permukaan atas berbilah putar dan tekanan yang didapati menunjukkan tekanan kecerunan yang dijangka, bergantung kepada sudut himpunan anggul yang berbeza.

KEYWORDS: pressure measurement; PSP; rotor blade; single-shot; lifetime

\section{INTRODUCTION}

To know the accurate distribution of spatial pressure on a rotor blade has been a critical research topic of many researchers for the understanding of complex rotorcraft aerodynamics. It is known that aerodynamics and acoustics such as blade-vortex interactions (BVI) can be studied by observing the unsteady pressure distributions around a blade tip. As conventional pressure measurement techniques [1], pressure taps and piezoelectric sensors have been mounted on a blade surface to measure pressure 
fluctuations but they have a limitation on spatial resolution as well as high cost for sensor installation. Pressure sensitive paint (PSP) has been developed as an advanced measurement technique for measuring global surface pressure fields. The principle of PSP is that the paint intensity are changed by concentration of oxygen on the model surface. Figure 1 shows basic components of a PSP system. The luminescent molecular probes are imbedded in a polymer binder form. On Excitation by light of the proper wavelength, the luminescence which is quenched by oxygen is detected by a CCD camera.

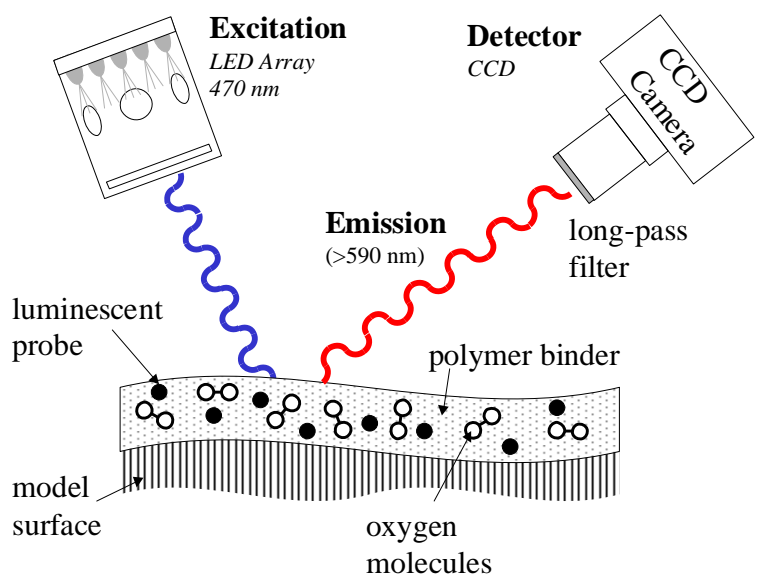

Fig. 1: Basic components of a PSP system [18].

The relationship between the luminescent intensity from PSP and oxygen concentration can be described by the Stern-Volmer relationship,

$$
\frac{I_{r e f}}{I}=A(T)+B(T) \frac{P}{P_{r e f}}
$$

where $P$ is air-pressure, $I$ is luminescent intensity and ref indicates reference conditions. $A(T)$ and $B(T)$ are calibration coefficients depending on temperature. PSPs are very sensitive about not only pressure but also temperature. The reference is used to eliminate the effects of non-uniform illumination and uneven paint coating. In case of wind tunnel test, the reference $I_{r e f}$ is taken when the air flow is off and $I$ is taken during test condition. Once the intensity ratio $I_{r e f} / I$ is known, and the $P_{r e f}$ is also known at the reference(windoff) condition, then the pressure at the test condition may be determined from Eq. (1).

Since pressure sensitive paint was found in a laboratory, many researchers who work with wind tunnels have been spent their time to increase measurement accuracy and to find new ways to capture images for various experimental configurations. To compensate temperature effect dual luminophor which is called binary paint was developed [2]. This paint contains two different luminophors; PtTFPL (platinum tetra porpholactone) and $\operatorname{MgTFPP(magnesium~tetra~porphine).~PtTFPL~is~oxygen-sensitive~and~its~image~is~used~as~}$ pressure data. MgTFPP is, however, sensitive to temperature and used as a reference. The PSPs have different characteristics depending on luminophore-binder combinations. Conventional polymer-based PSPs are not suitable for measuring surface pressure on a rotating blade due to response times as slow as seconds. Therefore, fast response paint is needed for application to unsteady flows. In order to decrease response time of PSP, porous pressure sensitive paint has been developed. Fig. 2 shows the difference between 
porous PSP and conventional polymer-based PSP. A porous PSP binder which improves the oxygen diffusion can allow oxygen molecules to easily interact with luminophores, so the PSP quickly responds to changes in oxygen concentrations. Comprehensive reviews of PSP are published by Bell et al. [3] and Liu et al. [4-5]. A review of unsteady and fast response PSP developments are described by Gregory et al. [6-7] and Asahi et al. [8].

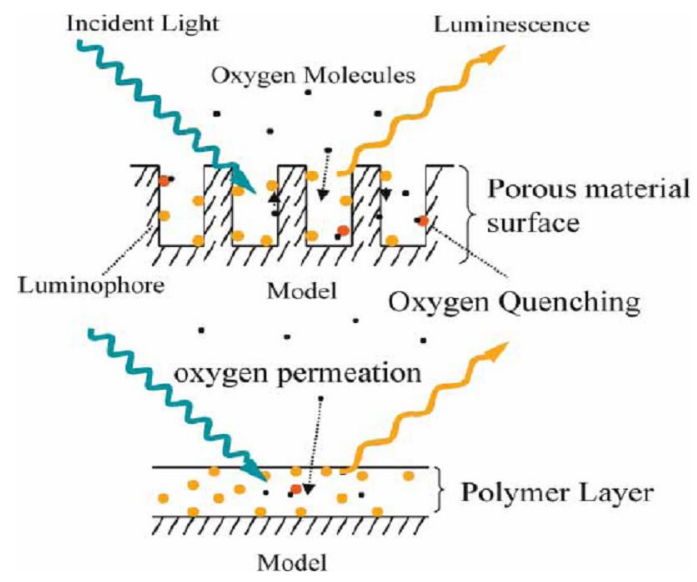

Fig. 2: Comparison of porous PSP and conventional PSP [19].

There are two methods for acquiring PSP data. One is an "Intensity" technique, and the other is a "Lifetime" technique [9-11]. In 1995, Burns et al. [12] used PSP for rotating compressor blade which was in steady condition. They adopted both intensity and lifetime methods to measure surface pressures. For unsteady pressures, lifetime method is necessary since intensity method gives us time averaged data only. The conventional lifetime method was qualitatively demonstrated by Wong et al. [13], where outer the $15 \%$ of each blade was painted with PSP. They used LED lamps as light source. However, the LED lamps are not eligible to obtain good images due to low light levels. Kumar [14] demonstrated the surface pressure measurements on rotating surfaces with both steady and unsteady pressure using lifetime-based single-shot methods. It is significant that he used a pulsed Nd:YAG laser instead of LED lamps as light source.

The objective of a present study is to find best way for measuring the unsteady pressure on a rotating blade. One and half meter sized small scale rotor test stand was used in hovering condition as a preliminary experiment prior to a forward flight condition. The experiment was carried out using lifetime-based single-shot method [14] and compared LED lamps with pulsed laser.

\section{EXPERIMENTAL}

The PSP experiment was performed using small scale rotor test stand. The main body was a RC helicopter that is called HERO $\square-500$. It had two blades and each blade length was $325 \mathrm{~mm}$ and its chord was about $33 \mathrm{~mm}$. The total radius of the rotor was $375 \mathrm{~mm}$ including a hub. The airfoil was symmetrical and maximum section thickness was $13 \%$ of the chord length as shown in Fig. 3. More specific rotor parameters are shown in Table 1. 


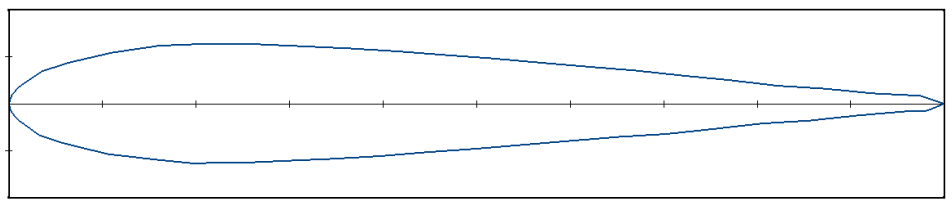

Fig. 3: Airfoil section geometry.

Table1. Rotor Parameters.

\begin{tabular}{|l|l|}
\hline Blade Length $(\mathrm{mm})$ & 325 \\
\hline Painted Length $(\mathrm{mm})$ & 90 \\
\hline Blade Chord $(\mathrm{mm})$ & 33 \\
\hline Rotor Radius $(\mathrm{mm})$ & 375 \\
\hline Rotational Speed (RPM) & 2050 \\
\hline Tip Speed (m/s) & 80 \\
\hline
\end{tabular}

The outer $27.7 \%$ of the blade was coated with a porous pressure sensitive paint (PPSP) and 10 markers for image alignment were located. This paint was developed by Innovative Scientific Solutions Inc, (ISSI). The porous paint was composed of three parts. Part A was water based ceramics slurry. Part B was acrylic polymer emulsion. Part C was Pt-based dye. Because of the part A and B, it was commonly called polymer/ceramic PSP (PC-PSP). This PSP binder was mixture of polymer and ceramic particles, so it needed to mix part $\mathrm{A}$ and part $\mathrm{B}$ as a metric before spraying the part $\mathrm{C}$. The mixing ratio is that the volume of part B is $4 \%$ of the part A volume. The PSP binder was coated using an airbrush tool, so that blade surface was uniformly covered with Part A and B mixture. Then, the coated blade should be dry in less than 30 minutes. After the blade surface was dry, part $\mathrm{C}$ which was Pt-based dye sprayed over the under coated mixture. Once the porous PSP was coated and the painted model used for a few hours under the excitation light, the signal was diminished due to photobleaching. In this case, it could apply more overspray to enhance the fluorescence of the blade and increase the signal to its previous level.

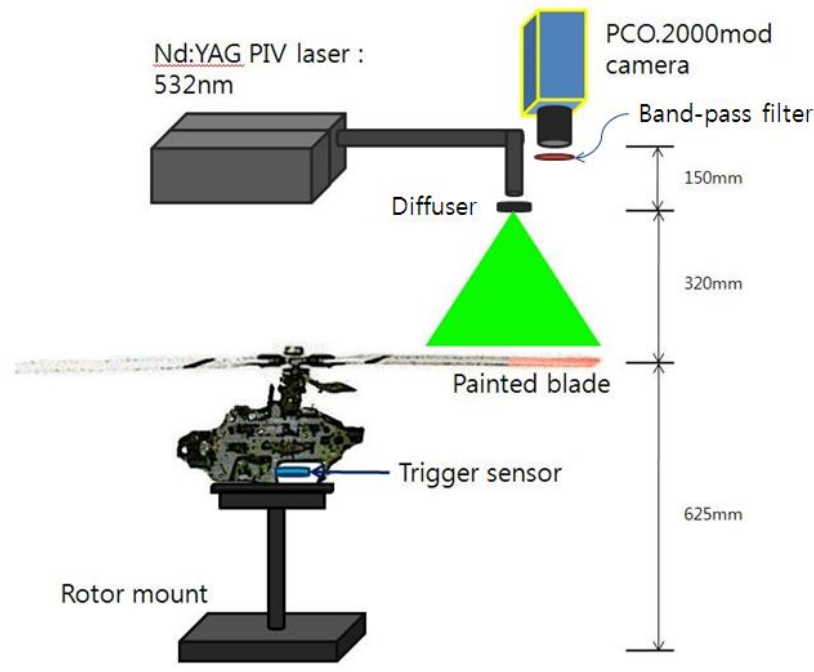

Fig. 4: Experimental set-up for a rotor blade pressure measurement. 
As a trigger signal for camera shutter and light source, a micro photo sensor was mounted under the rotor shaft. It could get a trigger signal where the rotor was in a certain azimuth angle. The trigger rate was a signal per revolution, so it could easily get the rotor RPM using micro photo sensor. Also, the trigger signal was plan to use the external signal in pulse generator. The experimental setup for a rotor blade PSP experiment is shown in Fig. 4, which includes a light source, and a photo detector as well as a CCD camera with an optical band-pass filter placed in front of the lens. LED lamps were also installed instead of pulsed laser as a light source.

The images were obtained by monochrome charge coupled device (CCD) camera which was a PCO.2000mod version. It has high resolution (2048 x 2048pixel) and low noise (down to 9e-rms). The camera can shot frequency up to 14.7 frames per second at full resolution, and minimum exposure time is $0.5 \mu \mathrm{s}$. To increase acquisition efficiency, the CCD chip was binned horizontally and vertically by 2 . For capturing luminescence image in single-shot method, the camera was used in a double exposure mode. In the double exposure mode, the CCD sensor has trigger acknowledgment delay $(0.2 \mu \mathrm{s})$ and intrinsic delay $(5.3 \mu \mathrm{s})$. The timings are shown in Fig. 5. The images were acquired from the CCD camera with Camware software.

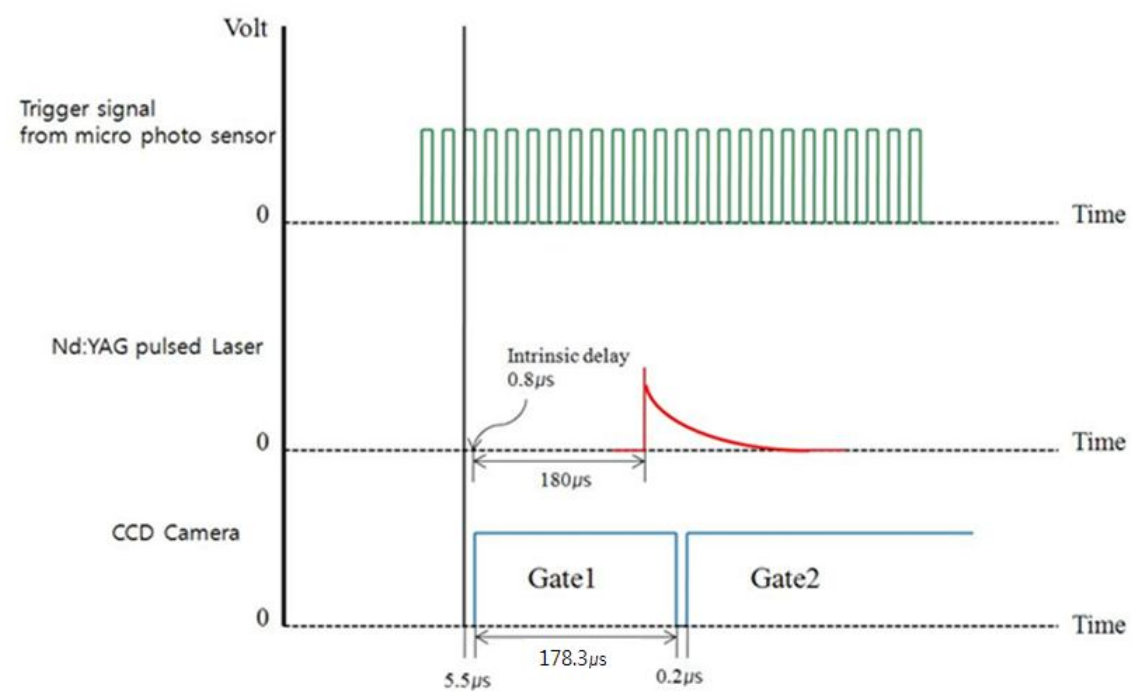

Fig. 5: Timing diagram for the rotor blade experiment.

Before the PSP experiment was performed using small scale rotor test stand, PSP calibration chamber was used in order to determine the time intervals of gate- 1 and gate- 2 . A small square coupon was painted with the porous PSP as same as the blade to confirm the relationship between the luminescence intensity and pressure on it. The temperature was kept constant at $20^{\circ} \mathrm{C}$ during the calibration and pressure was varied from $25 \mathrm{kPa}$ to $250 \mathrm{kPa}$ in 10 equal steps $(25 \mathrm{kPa})$. Once decide the gate-1 exposure time, the time of gate- 2 was automatically decided in double exposure mode. Therefore, the data was acquired by changing the time of gate- 1 and the results are shown in Fig. 6 . The reference pressure was $125 \mathrm{kPa}$.

A ratio of intensity $(\mathrm{G} 2 / \mathrm{G} 1)$ ref is a reference pressure value, and $\mathrm{G} 2 / \mathrm{G} 1$ is a pressure sensitive one. The plot between (G2/G1)ref/(G2/G1) and P/Pref represents Stern-Volmer relationship and the slope of the linear fit provides pressure sensitivity of the paint in two- 
gated lifetime measurement technique, which is well explained in the reference [14]. From these plots, the slope of lines increases as long as the gate-1 exposure time is increased. When the gate-1 exposure time was $15 \mu \mathrm{s}$, the pressure sensitivity of the paint was the best. However, the slope of line was not a linear, so it was difficult to apply the SternVolmer relationship. This non-linearity is due to low Signal to Noise Ratio (SNR). Finally, the gate- 1 exposure time was decided to equalize the gate- 1 and gate- 2 intensity ratios within $20 \%$ [20].

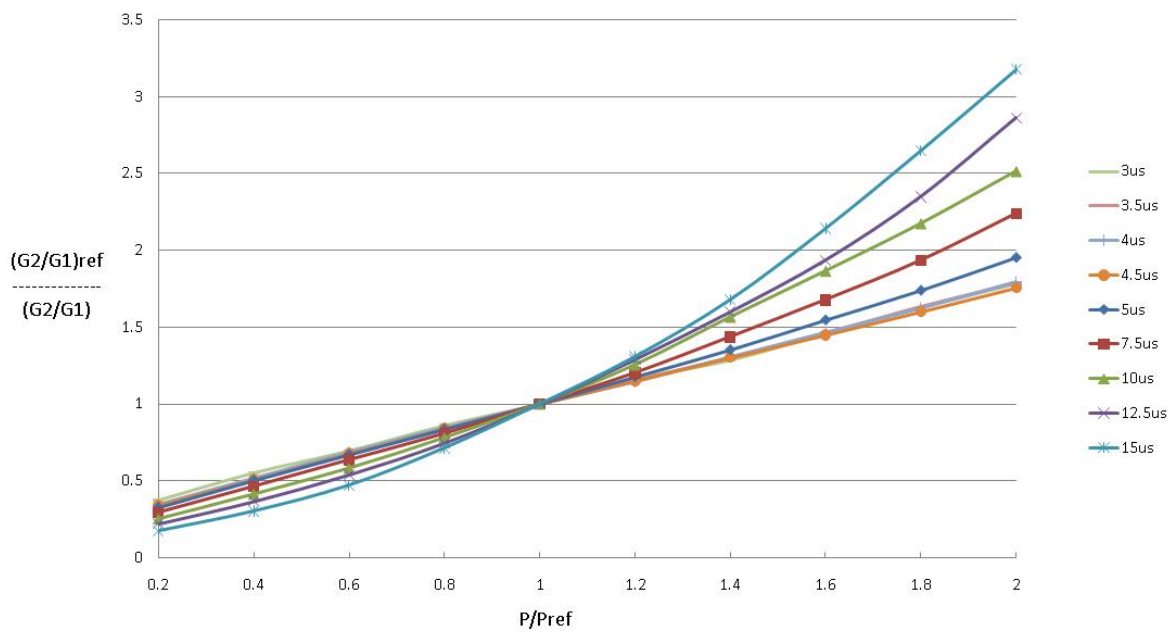

Fig. 6: The pressure sensitivity of varied gate-1 exposure time.

LED lamps and pulsed Nd:YAG laser were attempted as a light source. At first, Six LED lamps were installed around the CCD camera. They provided uniform and stable illumination for pressure and temperature sensitive paint measurements. Each LED lamp had $400 \mathrm{~nm}$ wavelength and all lamps were synchronized with one trigger pulse from photo sensor. Secondly, a pulsed Nd:YAG laser that had been used for PIV measurement was used as an excitation source. The laser's wavelength was $532 \mathrm{~nm}$. Using a laser as excitation source increased the signal-to-noise ratio (SNR) because the PSP response intensity is a function of both the pressure field and the illumination field. The laser was emitted with a Q-switch delay of $180 \mu$ s from a flash lamp excitation and the CCD camera was set synchronous to the laser. For the control the each signal time, a Quantum Composer delay generator (model 9514) was used. After comparing the LED lamps with pulsed laser, pulsed laser was selected for the experiment since the LED lamps were found to have low intensity for excitation.

The PSP data was collected using lifetime-based single-shot method. The rotational speed of the rotor was RPM 2,050 as the test pressure condition, and reference pressure condition was RPM 300. The angle of attack for each blade could control simultaneously, so the PSP data was obtained from three different angles of attack which were $5^{\circ}, 8^{\circ}$, and $12^{\circ}$. The dark images also acquired during the experiment to apply the post-image processing. The black screens were installed around the model in order to block out all of the lights except laser light. Atmospheric pressure was 100,860 $\mathrm{Pa}$ and ambient temperature was $24^{\circ} \mathrm{C}$ during the PSP experiment. Suppose that the forward flight direction was azimuth $180^{\circ}$. The camera shutter was open when the blade was located at $270^{\circ}$ azimuth angle. For the single-shot lifetime technique, images were acquired using double exposure mode. The laser pulsed with a Q-switch delay of $180 \mu$ s and it had intrinsic delay of around $0.8 \mu \mathrm{s}$. The CCD camera at double exposure mode had total 
initial delay of $5.5 \mu$ s and the lifetime of gate- 1 was $3 \mu \mathrm{s}$, so total gate- 1 time was $178.3 \mu \mathrm{s}$. As it called single-shot, each image was collected by only one laser pulse light.

After all images were acquired, the post-image processing was used by OMS 3.0 software which was developed by ISSI and LabVIEW programs.

\section{RESULTS AND DISCUSSION}

By comparing six LED lamps with pulsed Nd:YAG laser as excitation source, the image obtained from pulsed laser shows stronger intensity than LED lamps. Figure 7 shows the intensity of six LED lamps and Fig. 8 shows the intensity of the pulsed Nd:YAG laser. The intensity images were taken by applying the single-shot lifetime technique. As shown in Fig. 7 and 8, the measured intensities using the pulsed laser are much higher than the intensities using six LED lamps. The results are from different energy power. The power of each LED lamp is about $2.7 \mathrm{~W}$. If the six lamps are flashing for $3 \mu \mathrm{s}$, the power could be transferred to $48.6 \mu \mathrm{J}$. On the other hand, the pulsed Nd:YAG laser produces a $200 \mathrm{~mJ}$ per pulse $(8 \mathrm{~ns})$. It is enough power to apply the single-shot life time technique. Since the LED lamps were found to have low intensity for excitation, pulsed Nd:YAG laser was selected as a light source

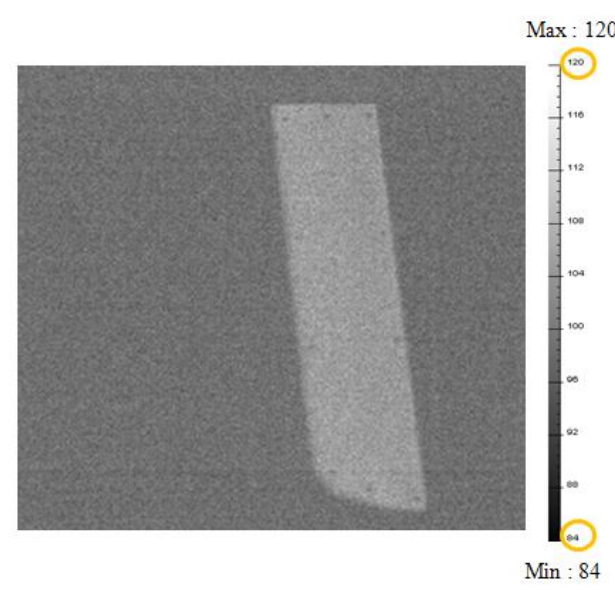

Fig. 7: The intensity of six LED lamps.

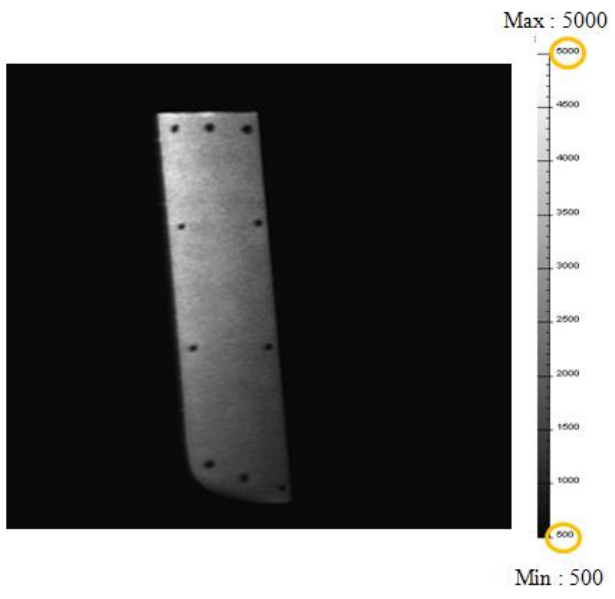

Fig. 8: The intensity of pulsed Nd:YAG laser.

The final result images were obtained after post-image processing procedure. Figure 9 shows the measured surface pressure distributions on an upper surface of the rotor blade depending on the collective pitch angle. The temperature sensitivity of the porous paint was not considered even though the porous paint had temperature sensitivity. For this reason, the PSP experiment was performed to qualitatively analyze the pressure distribution on the rotor blade, not quantitatively.

As shown in the results, noticeable pressure gradient was acquired using single-shot lifetime technique with pulsed Nd:YAG laser. At the collective pitch angle of $5^{\circ}$ condition, pressure distribution shows a high pressure region near the trailing edge and blade-tip area. At the $8^{\circ}$ collective pitch angle condition, a lower pressure region exists near the leading edge of the blade and the pressure is increase in the chord wise direction toward the trailing edge. At the $12^{\circ}$ collective pitch angle condition, pressure distribution on the blade is much lower than other angles. In this condition, the blades are expected to have a 
mixmum lift-force acting on the model. As expected, the pressure on an upper surface of the rotor blade is decrease while increasing the collective pitch angle

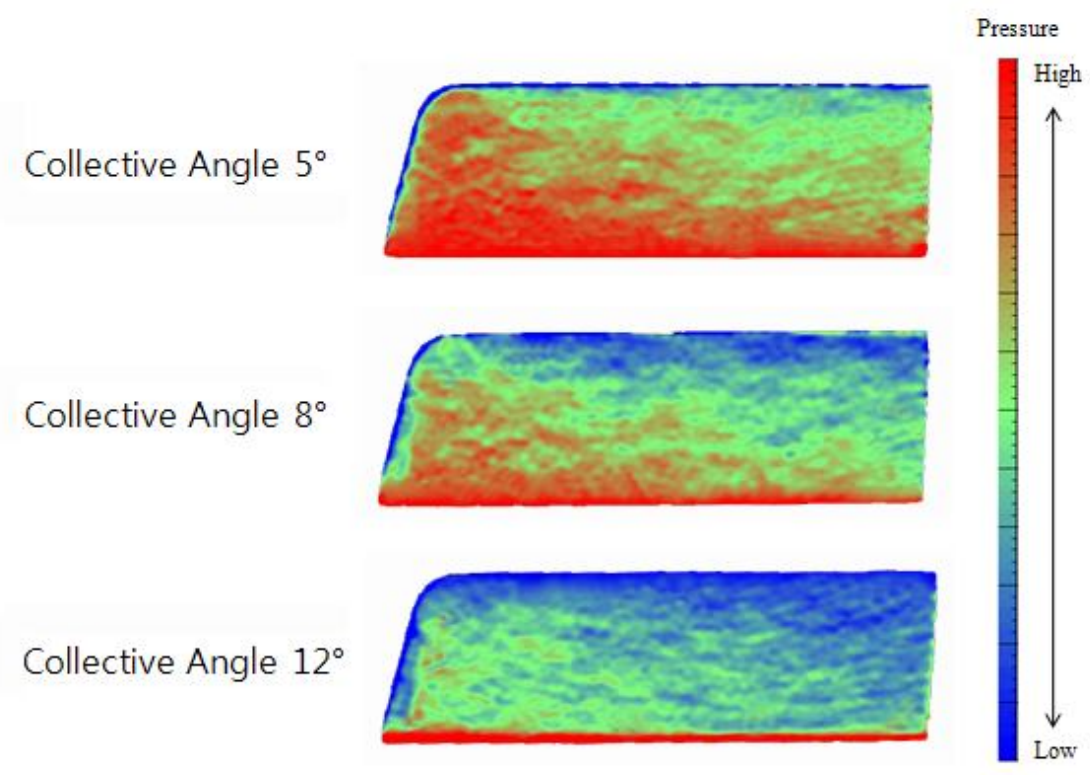

Fig. 9: The results of pressure distributions on a rotor blade.

Every image can find sharp high pressure distributions at the trailing edge. These sharp pressure distributions are made after post-image processing procedure that used test condition (wind-on) images and reference condition (wind-off) images. The test condition images were acquired when the rotating speed of the blade was RPM 2050 with a tip speed of around $80 \mathrm{~m} / \mathrm{s}$. In case of the test condition, the rotor blades slightly moved up due to the lift-force. On the other hand, the reference condition images were captured when the rotating speed of the blade was RPM 300. In case of the reference condition, the rotor blades could not move up because the lift-force was not enough to raise the blades. The height of installed CCD camera was fixed, so the acquired blade images' sizes were different due to small change of the rotor blades' height. These mismatched images made sharp high pressure distributions at the trailing edge.

\section{COUNCLUSION}

This PSP experiment was performed to verify a possibility of pressure distribution measurements on a rotor blade using PSP. LED lamps and pulsed Nd:YAG laser were attempted to compare measurement ability. The porous pressure sensitive paint was used for decrease the response time and the experiment was only demonstrated in hovering condition at the KARI low speed wind tunnel laboratory. In case of hovering condition, the pressure on the upper surface rotor blade is steady state. The next step, however, is to measure unsteady pressure distribution for the forward flight condition to see as averaged pressure distributions with respect to blade azimuth angle. As discussed earlier, the high power light source is required to use the single-shot lifetime technique for get better images. 
Although remarkable PSP techniques were used with pulsed Nd:YAG laser for strong light source, several problems were also discovered through this PSP experiment. At first, the porous PSP was so sensitive to light source that the experiment could not be performed for a long time. For this reason, the useless light had to be blocked all the time to enhance luminescence time. Second, the result images involve some error factors such as sharp high pressure region at the trailing edge. More accurate post-image processing is essential to reduce the error factors. Therefore, image processing techniques will be also developed to decrease the PSP uncertainty. Finally, in order to measure quantitative pressure on a rotor blade with porous PSP, the relationship among the luminescence intensity signal, air pressure, and temperature should be precisely controlled.

\section{REFERENCES}

[1] F. X. Caradonna, and C. Tung, "Experimental and Analytical Studies of a Model Helicopter Rotor in Hover" NASA-TM-81232

[2] G. E. Khalil, C. Costin, J. Crafton, G. Jones, S. Grenoble, M. Gouterman, J. B. Callis, and L. R. Dalton, "Dual-luminopher pressure-sensitive paint - I. Ratio of reference to sensor giving a small temperature dependency". Sensor and Actuators B: Chemical, vol. 97, 2003, pp.1321.

[3] J. H. Bell, E. T. Schairer, L. A. Hand, and R. D. Mehta, "Surface Pressure measurements using luminescent coatings". Annual Review of Fluid Mechanics, vol. 33, 2001, pp.155-206.

[4] T. Liu, B. T. Campbell, S. P. Burns, J. P. Sullivan, "Temperature-and Pressure-Sensitive Luminescent Paints in Aerodynamics," Applied Mechanics Reviews, vol. 50, no.4, pp.227246, 1997.

[5] T. Liu, J. P. Sullivan, "Pressure and temperature sensitive paints," Springer, New York, 2005.

[6] J. W. Gregory, "Porous pressure-sensitive paint for measurement of unsteady pressures in turbomachinery" 42nd AIAA Aerospace Sciences Meeting and Exhibit, Reno, NV, January, 2004, AIAA 2004-0294.

[7] J. W. Gergory, K. Asai, M kameda, T. Liu, and J.P. Sullivan, "A review of pressuresensitive paint for high-speed and unsteady aerodynamics" Proceedings of the Insitiutitution of Mechanical Engineers, Part G, Journal of Aerospace Engineering, vol. 222, no.2, pp 249290.

[8] K, Asai, K. Nakakita, M. Kameda, K. Teduka, "Recent topics in fast-responding pressuresensitive paint technology at national aerospace laboratory" Instrumentation in Aerospace Simulation Facilities, 19th International Congress on ICIASF 2001, Cleveland, OH, Auguest, 2001, pp.25-36.

[9] R. H. Engler, and C. Klein, "DLR PSP System: Intensity and Lifetime measurements" Instrumentation in Aerospace Simulation Facilities, $17^{\text {th }}$ International Congress on ICIASF 1997, Pacific Grove, CA, pp.46-56.

[10] K. Mitsuo, K. Asai, A. Rakahashi, and H. Mizushima, "Advanced lifetime PSP imaging system for pressure and temperature field measurement" Measurement Science and Technology, vol. 17, no. 6, June, 2006. pp.1282-1291.

[11] A. N. Watkins, J. D. Jordan, B. D. Leighty, J. L. Ingram, and D.M. Oglesby, "Development of next generation lifetime PSP imaging systems" Instrumentation in Aerospace Simulation Facilities, 20th International Congress on ICIASF '03, August, 2003. pp. 372-382.

[12] S. P. Burns and J. P. Sullivan, "The use of pressure sensitive paints on rotating machinery" Instrumentation in Aerospace Simulation Facilities, 16th ICIASF'95 Record, 18-21 July, 1995, pp. 32.1-32.14. 
[13] O. D. Wong, A. Neal Watkins, and JoAnne L. Ingram, "Pressure sensitive paint measurements on 15\% scale rotor blades in hover" 35 th AIAA Fluid Dynamics Conference and Exhibit, San Francisco, CA, June, 2005, AIAA 2005-5008.

[14] P. Kumar, "Development of a single-shot lifetime PSP measurement technique for rotating surfaces" M.S. Thesis, The Ohio State University, Columbus, OH, 2010.

[15] J. P. Hubner, J. D. Abbitt, B. F. Carroll, "Pressure measurements on rotating machinery using lifetime imaging of pressure sensitive paint" $32^{\text {nd }}$ AIAA/ASME/SAE/ASEE Joint Propulsion Conference and Exhibit, Lake Buena Vista, FL, 1-3 July, 1996, pp.1-9.

[16] Y. Sakamura, T. Suzuki, M. Matsumoto, G. Masuya, and Y. Ikeda, "Optical measurements of high-frequency pressure fluctuations using a pressure-sensitive paint and Cassegrain optics" Journal of Measurement Science and Technology, vol. 13, no.10, October, 2002. pp. 1591-1598.

[17] M. Kameda, T. Tabei, K. Nakakita, H. Sakaue, K. Asai, "Imaging measurement of unsteady pressure fluctuation on a delta wing by an anodized aluminum PSP" Measurement Science and Technology, vol. 16, no12, 2005.

[18] L. Goss, G. Jones, J. Crafton, S. Fonov, V. Fonov, "Temperature Compensation for Lifetime-Based Pressure Sensitive Paint Systems" Instrumentation in Aerospace Simulation Facilities, 21st International Congress on ICIASF 2005, Sendai, Japan, pp.283-292

[19] H. Sakaue, "Porous pressure sensitive paints for aerodynamic applications" MS Thesis, School of Aeronautics and Astronautics, Purdue University, West Lafayette, IN, 1999.

[20] T. J. Juliano, P. Kumar, D. Peng, J. W. Gregory, J. Crafton, and S. Fonov, "Single-shot, lifetime-based pressure-sensitive paint for rotating blades" Measurement Science and Technology, vol. 22, no.8, June, 2011. 